Available online on 15.07.2018 at http://jddtonline.info
Journal of Drug Delivery and Therapeutics
Open Access to Pharmaceutical and Medical Research
$\begin{gathered}\text { O 2011-18, publisher and licensee JDDT, This is an Open Access article which permits unrestricted non- } \\ \text { commercial use, provided the original work is properly cited }\end{gathered}$

Open $\odot$ Access

Review Article

\title{
FAST DISSOLVING ORAL FILMS: A TABULAR UPDATE
}

\author{
Ashish Jain $^{1 *}$, Harish C. Ahirwar ${ }^{2}$, Shivam Tayal ${ }^{1,2}$, Pradeep K. Mohanty ${ }^{1}$ \\ ${ }^{1}$ School of Pharmacy, LNCT University, Kolar Road, Bhopal, M.P., India \\ ${ }^{2}$ Sagar Institute of Pharmacy and Technology, Bhopal, M.P., India
}

\begin{abstract}
Fast-dissolving oral films have emerged as alternative dosage forms for the patients who experience difficulties in swallowing traditional oral solid dosage forms such as tablets, capsules, and syrups etc. These dosage forms disintegrate or dissolve very quickly within seconds when placed in the mouth cavity without need of water or chewing. Due to fast dissolution it provide faster onset of action, bypassing the first pass metabolism, reducing gastric degradation and metabolism of drugs and thus enhance their oral bioavailability. These properties of oral films with patient convenience and compliance made popular and accepted dosage form for pediatric and geriatric as well as adult population. These formulations are suitable for cough, cold, sore throat, allergenic conditions, nausea, pain, hypertension and CNS disorders, epilepsy and many more diseases. The present review provides up to date review in fast dissolving oral films in tabular form so researches can easily track various technologies/research in design and development of oral fast dissolving film.
\end{abstract}

Keywords: Mouth dissolving films, Oral dispersible film, Oral dissolving film, Oral disintegrating film.

Article Info: Received 16 Feb, 2018; Review Completed 23 May 2018; Accepted 24 May 2018; Available online 15 July 2018

Cite this article as:

Jain A, Ahirwar HC, Tayal S, Mohanty PK, Fast dissolving oral films: a tabular update, Journal of Drug Delivery and Therapeutics. 2018; 8(4):10-19 DOI: http://dx.doi.org/10.22270/jddt.v8i4.1724

*Address for Correspondence:

Ashish Jain, School of Pharmacy, LNCT University, Kolar Road, Bhopal, M.P., India

\section{INTRODUCTION}

Oral route is a most preferred route of drug administration for systemic effect due to its ease of administration, non-invasiveness, adaptability, patient compliance and acceptability ${ }^{1,2}$. Tablet is the most preferred dosage form due to ease of manufacturing, transportation and more patient compliance ${ }^{3}$. Generally geriatric, pediatric, nauseous, bed ridden and noncompliance patients experience difficulties in swallowing the conventional oral dosage form and do not take their medicines as prescribed. It is estimated that $50 \%$ of the population was affected by this problem, which finally results in a higher chance of noncompliance \& ineffective therapy ${ }^{4}$.

The elderly constitute a major portion of today's population mainly because of increased life expectancy of individuals ${ }^{5}$. Dysphagia or difficulty in swallowing is common problem, this disorder is coupled with several medical conditions including stroke, AIDS, thyroidectomy, Parkinson's disease, head and neck radiation therapy and other neurological disorders as well as encephalopathy ${ }^{6}$. The most common complaint with tablet is size, fear of chocking. The problem of swallowing tablets is more evident in geriatric and pediatric patients, as well as travelling patients who may not have ready access to water ${ }^{7}$.

To overcome this Oral fast disintegrating drug delivery systems were developed, these systems were initially developed within the late Seventies as an alternative to tablets, capsules and syrups for pediatric \& geriatric patients who experience difficulties in swallowing traditional oral solid dosage forms. These dosage forms either dissolve or disintegrate generally within a 3 minute in mouth, without need of water. Oral fast Disintegrating dosage form have started gaining popularity \& acceptance as new drug delivery system due to better patient compliance ${ }^{8}$. 
Oral fast disintegrating dosage form consists of mouth dissolving tablets \& fast dissolving films. Mouth dissolving tablets associated with many problems like leave residues in mouth which causes feeling of grittiness in mouth; there is a fear of choking, difficulty in swallowing tablets. To beat the issues of mouth dissolving tablets, a new drug delivery system for the oral delivery of the drugs, was investigated which is known as Fast dissolving films/oral dispersible film/ mouth dissolving films / oral disintegrating film/ oral dissolving film ${ }^{9}$.

Fast dissolving oral film was developed based on the technology of the transdermal patches for oral delivery of drugs. ${ }^{10}$. The delivery system consists of a thin film of the size of a postage stamp, which is placed on the patient's tongue or mucosal tissue, where it instantly hydrates by absorbing saliva; the film then rapidly disintegrates and dissolves to release the drug for oral mucosal absorption. This fast dissolving action is primarily due to the large surface area of the film, which wets quickly when exposed to the moist oral environment ${ }^{11}$.

\subsection{Special features of fast dissolving oral films ${ }^{12,13}$}

$>$ Thin elegant film

$>$ Available in various size and shapes

$>$ Unobtrusive

$>$ Excellent mucoadhesion

$>$ Fast disintegration and dissolution

$>$ Rapid drug release

$>$ Bypasses first pass effect

\subsection{Advantage of orally fast dissolving oral films ${ }^{13-16}$}

$>$ No need of water for administration.

> Convenient for pediatric, geriatric and dysphasic patients having difficulty in swallowing.

$>$ Rapid disintegrating and dissolution in the oral cavity due to larger surface area of films.

$>$ Rapid onset of action with increased bioavailability due to bypassing hepatic first pass effect.

$>$ Reduce dose, enhances the efficacy and safety profile of the drug with reduced side effects.

$>$ Flexible and portable in nature so they provide ease in handling, transportation and storage.

$>$ Ease of administration to mentally ill, disabled, uncooperative patients and the patients who are on reduced liquid intake plans or are nauseated.

$>$ Beneficial in cases such as motion sickness, acute pain, sudden allergic attack, asthmatic attack and coughing, where an ultra rapid onset of action is required.

$>$ Stability for longer duration of time, since the drug remains in solid dosage form till it is consumed.

$>$ Accuracy in dose as compared to liquid formulations.

$>$ Pleasant mouth feel, leave negligible or no residue in the mouth after administration.

\subsection{Limitations of fast dissolving oral films:-}

$>$ High doses cannot be incorporated.

$>$ Excessive bitter drugs are not feasible.

$>$ Dose uniformity is a technical challenge.
$>$ They require special packaging for the products stability and safety.

$>$ Drugs which irritate the oral mucosa cannot be administered by this route.

2. Formulation of fast dissolving films: - Fast dissolving Oral films include various ingredients for its formulation such as

* Active pharmaceutical ingredient

* Film forming polymers

* Plasticizer

* Sweetening agent

* Saliva stimulating agent

* Surfactants

* Flavoring agent

* Coloring agent

\subsection{The ideal characteristics of drug to be selected} $13,16,17$

$>$ The drug should have pleasant taste.

$>$ The therapeutic dose of the drug should not be greater than $40 \mathrm{mg}$.

$>$ The drug should have small molecular size and low molecular weight.

$>\quad$ The drug should have good solubility and stability in water as well as in saliva.

$>$ It should be partially unionized at the $\mathrm{pH}$ of oral cavity.

$>$ The drug should exhibit low sensitivity to environmental conditions.

$>\quad$ It should have the ability to permeate oral mucosal tissue.

\subsection{Film Forming Polymers}

Polymer is the major and most essential component of FDOFs ${ }^{4}$. A variety of polymers are available for preparation of oral film and these are used in the concentration of about $40-45 \% \mathrm{w} / \mathrm{w}$ of total film weight but can be increased up to $65 \% \mathrm{w} / \mathrm{w}$ of film weight alone or in combination to obtain desired properties of oral film ${ }^{10,18}$. The film obtained should be tough enough so that there may not be any damage while handling or during transportation. The robustness of the film depends on the type of polymer and the amount in the formulation ${ }^{12,19}$. The physicochemical characteristic of the polymer or polymers selected for film formulation play a vital role in determining the resultant disintegration time of the prepared film ${ }^{20}$.

Table 1: List of some film forming polymers ${ }^{16}$

\begin{tabular}{|l|l|}
\hline $\begin{array}{l}\text { Natural } \\
\text { polymer }\end{array}$ & Synthetic polymer \\
\hline Starch & Hydroxy propyl methyl cellulose \\
\hline Pectin & Poly vinyl pyrolidone (PVP) \\
\hline gelatin & Polyvinyl alcohol (PVA) \\
\hline Sodium alginate & Sodium Carboxy methyl cellulose \\
\hline Maltodextrin & Poly ethylene oxide (PEO) \\
\hline Pullulan & Kollicoat IR \\
\hline Xanthan & Hydroxy propyl cellulose (HPC) \\
\hline $\begin{array}{l}\text { Polymerized } \\
\text { rosin }\end{array}$ & Hydroxy ethyl cellulose (HEC) \\
\hline Gum acacia & Methyl cellulose (MC) \\
\hline
\end{tabular}




\subsection{Ideal properties of the film forming polymers ${ }^{21-}$}

> The polymer employed should be non-toxic, nonirritant and devoid of any leachable impurities.

$>$ It should be tasteless.

$>$ It should have good wetting and spread ability property.

$>$ The polymer should exhibit sufficient peel, shear and tensile strengths.

$>$ The polymer should be cheap and readily available.

$>$ It should have long shelf life.

$>$ It should not cause any secondary infections in the oral mucosa/ dental region.

$>$ It should have a good mouth feel property.

$>$ It would be ideal to have a polymer that would have local enzyme inhibition action along

\subsection{Manufacturing Methods}

One or combination of the following process can be used to manufacture the mouth dissolving films ${ }^{11}$.

i) Solvent casting

ii) Semisolid casting iii) Hot melt extrusion

iv) Solid dispersion extrusion

v) Rolling

2.5 Evaluating parameters ${ }^{11}$

1) Mechanical properties

a) Tensile strength, b) Elastic modulus, c) \%

Elongation, d) Folding endurance,

2) Morphology study

3) Swelling property

4) Contact angle

5) In vitro disintegration time

6) In vitro dissolution studies

7) Determination of dissolution rate by conductivity method

\section{3: Current Research in fast dissolving oral film:}

Various researches in the field of fast dissolving film are soon the tabular form as following.

\begin{tabular}{|c|c|c|}
\hline $\begin{array}{l}\text { Researchers } \\
\text { / Year }\end{array}$ & Title of work & Work summary and Findings \\
\hline $\begin{array}{l}\text { Ehtezazi T et } \\
\text { al., } \\
(2018)\end{array}$ & $\begin{array}{l}\text { The application of } 3 \mathrm{~d} \\
\text { printing in the formulation } \\
\text { of multilayered fast } \\
\text { dissolving oral films }\end{array}$ & $\begin{array}{l}\text { With application of 3D Printing Multilayered Fast Dissolving Oral } \\
\text { Films were prepared with taste-masking layers being separated from } \\
\text { drug layer. Filaments were prepared containing polyethylene oxide with } \\
\text { ibuprofen or paracetamol as model drugs at } 60^{\circ} \mathrm{C} \text {. In conclusion, this } \\
\text { study provides proof-of-concept for the manufacturing of FDFs by } \\
\text { using 3D printing }{ }^{2} \text {. }\end{array}$ \\
\hline $\begin{array}{l}\text { Patil D, et } \\
\text { al., (2018) }\end{array}$ & $\begin{array}{l}\text { Design and development of } \\
\text { fast dissolving film of } \\
\text { telmisartan. }\end{array}$ & $\begin{array}{l}\text { Main objective was to increase the release time of Telmisartan from } \\
\text { the dosage form at the site of absorption thus leading to enhance } \\
\text { absorption and bioavailability. Six formulations were prepared using } \\
\text { Poly vinyl pyrrolidone as a film forming agent. Propylene glycol and } \\
\text { Polyethylene glycol } 400 \text { were used as a plasticizer. This system was } \\
\text { developed by using Solvent Casting Method. Films were evaluated for } \\
\text { Content uniformity, Thickness, Folding endurance, disintegration time } \\
\text { and dissolution studies }{ }^{23} \text {. }\end{array}$ \\
\hline $\begin{array}{l}\text { Song Q et } \\
\text { al., (2018) }\end{array}$ & $\begin{array}{l}\text { Development of a fast } \\
\text { dissolving sublingual film } \\
\text { containing meloxicam } \\
\text { nanocrystals for enhanced } \\
\text { dissolution and earlier } \\
\text { absorption. }\end{array}$ & $\begin{array}{l}\text { Crystalline orally-dissolving films of ropinirole were prepared. The oral } \\
\text { films exhibit fast disintegration, dissolution; and are physical stable. } \\
\text { The oral films are non-cytotoxic and metabolically stable in oral } \\
\text { mucosal tissues. The oral films exhibit fast drug absorption. } \\
\text { The bioavailability of ropinirole was significantly improved by the oral } \\
\text { films }{ }^{24} \text {. }\end{array}$ \\
\hline $\begin{array}{l}\text { Kadam V } \\
\text { et al., (2017) }\end{array}$ & $\begin{array}{l}\text { Formulation and evaluation } \\
\text { of fast dissolving oral film } \\
\text { of metoclopramide } \mathrm{HCl} \text {. }\end{array}$ & $\begin{array}{l}\text { Metoclopramide } \mathrm{HCl} \text { film formulations were prepared by solvent } \\
\text { casting technique using various film forming polymer and plasticizer. } \\
\text { The prepared films were evaluated for their appearance, thickness, } \\
\text { folding endurance, weight uniformity, \% drug content, surface } \mathrm{pH} \text {, tack } \\
\text { test, disintegration time and in-vitro dissolution studies }{ }^{25} \text {. }\end{array}$ \\
\hline $\begin{array}{l}\text { Bajpai S } \\
\text { et al., (2017) }\end{array}$ & $\begin{array}{l}\text { Dynamic release of } \\
\text { Amoxicillin from Orally } \\
\text { Dissolving Film (ODF) } \\
\text { composed of Casein and } \\
\text { Sodium alginate. }\end{array}$ & $\begin{array}{l}\text { The films were prepared by the physical blending of the two polymers, } \\
\text { namely casein and alginate. The dissolution/ disintegration properties } \\
\text { were investigated by putting a pre-weighed piece of the film in artificial } \\
\text { saliva. The release kinetics of drug Amoxicillin was also studied. The } \\
\text { release of drug Amoxicillin was found to follow 'zero order kinetics' } \\
\text { which is the most desirable for best therapeutics. These films bear } \\
\text { potential to be used for delivery of fast relieving drugs through oral } \\
\text { mucosa route }{ }^{26} \text {. }\end{array}$ \\
\hline $\begin{array}{l}\text { Patil et al., } \\
(2016)\end{array}$ & $\begin{array}{l}\text { Design, evaluation and } \\
\text { characterization of rapidly } \\
\text { dissolving oral strips of }\end{array}$ & $\begin{array}{l}\text { Oral strips of metoprolol succinate, an anti-hypertensive agent prepared } \\
\text { by solvent casting technique The formulation containing 1:3 drug- } \\
\text { polyme ratio showed optimum performance when compared to other }\end{array}$ \\
\hline
\end{tabular}




\begin{tabular}{|c|c|c|}
\hline & metoprolol succinate. & $\begin{array}{l}\text { formulations with disintegration time of } 13.66 \mathrm{sec} \text {, folding endurance }> \\
246 \text {, tensile strength } 3.54 \mathrm{~N} / \mathrm{mm} 2 \text {, percentage elongation } 26 \% \text {, drug } \\
\text { content } 98.45 \% \text { and in-vitro drug release } 98.45 \% \text { in } 7 \text { minutes }{ }^{27} \text {. }\end{array}$ \\
\hline $\begin{array}{l}\text { Reddy et al., } \\
(2016)\end{array}$ & $\begin{array}{l}\text { Formulation and evaluation } \\
\text { of fast dissolving buccal } \\
\text { films containing } \\
\text { zolmitriptan. }\end{array}$ & $\begin{array}{l}\text { Buccal films of zolmitriptan by solvent casting technique prepared by } \\
\text { using HPMC-E5, HPMC-E15, and HPMC-E50 as film forming } \\
\text { polymers and Propylene glycol as plasticizer. Citric acid was used as } \\
\text { saliva stimulating agent and sodium saccharine as artificial sweetening } \\
\text { agent. The formulation containing 300mg HPMC E-15 and } 0.14 \% \mathrm{w} / \mathrm{w} \\
\text { of propylene glycol was selected as best formulation with disintegration } \\
\text { time of } 56 \text { seconds and showed in-vitro drug release of } 99.89 \% \text { in } 12 \\
\text { minutes } 28 \text {. }\end{array}$ \\
\hline $\begin{array}{l}\text { Newton } e t \\
\text { al., (2016) }\end{array}$ & $\begin{array}{l}\text { Fabrication and evaluation } \\
\text { of fast disintegrating oral } \\
\text { hybrid films of propranolol } \\
\text { hydrochloride by using } \\
\text { pectin and synthetic } \\
\text { polymers. }\end{array}$ & $\begin{array}{l}\text { The Propranolol } \mathrm{HCl} \text { oro-dispersible films were formulated using } \\
\text { natural water soluble polymers such as pectin and synthetic water } \\
\text { soluble polymers such as HPMC E15LV, HPMC regular, Carbopol and } \\
\text { PVA, as film forming polymers. Glycerin as plasticizer, citric acid as } \\
\text { saliva stimulating agent and mannitol as sweetening agent. The } \\
\text { dissolution kinetic studies of all the formulations were performed. } \\
\text { Complete drug release was found from all the formulations after } 12 \\
\text { minutes. The formulations followed zero order release. }{ }^{29} \text {. }\end{array}$ \\
\hline $\begin{array}{l}\text { Nair et al., } \\
(2016)\end{array}$ & $\begin{array}{l}\text { Development and } \\
\text { Evaluation of fast dissolving } \\
\text { oral thin film containing } \\
\text { prochlorperazine maleate }\end{array}$ & $\begin{array}{l}\text { Fast dissolving oral thin films of Prochlorperazine maleate were } \\
\text { prepared by solvent casting method using HPMC E15 as film forming } \\
\text { polymer, glycerol and propylene glycol as plasticizers, tween- } 80 \text { as } \\
\text { surfactant, mannitol as sweetening agent and citric acid as saliva } \\
\text { stimulating agent. The prepared films were evaluated for physical } \\
\text { appearance test, surface pH, thickness, weight variation, tensile } \\
\text { strength, content uniformity, in-vitro disintegration test and in-vitro } \\
\text { dissolution test. All the films were found to show satisfactory results }{ }^{30} \text {. }\end{array}$ \\
\hline $\begin{array}{l}\text { Pathan et al., } \\
(2016)\end{array}$ & $\begin{array}{l}\text { Formulation and evaluation } \\
\text { of fast dissolving oral film } \\
\text { of promethazine } \\
\text { hydrochloride using } \\
\text { different surfactant }\end{array}$ & $\begin{array}{l}\text { Fast dissolving Oral films of Promethazine hydrochloride a strong } \\
\text { antihistamine used to reduce nausea, motion sickness and improve } \\
\text { bioavailability. The films were prepared using Hydroxy propylmethyl } \\
\text { cellulose E15 as a film base and Poly Ethylene Glycol } 400 \text { as a } \\
\text { plasticizer by solvent casting method. SLS (Sodium Lauryl Sulfate) as } \\
\text { surfactant and MCC (Micro Crystalline Cellulose) used as } \\
\text { disintegrating agent in different concentration. Sucrose used as a } \\
\text { sweetening agent and strawberry as a flavoring agent. }{ }^{31} \text {. }\end{array}$ \\
\hline $\begin{array}{l}\text { Soni et al., } \\
(2016)\end{array}$ & $\begin{array}{l}\text { Formulation and evaluation } \\
\text { of fast dissolving film of } \\
\text { lurasidone } \mathrm{HCl} \text {. }\end{array}$ & $\begin{array}{l}\text { Fast dissolving film of lurasidone, a poorly soluble antipsychotic drug, } \\
\text { used for the treatment of schizophrenia. To make it soluble it was } \\
\text { formulated as drug- inclusion complex by kneading method using } \beta \text { - } \\
\text { cyclodextrin in } 1: 1 \text { ratio to enhance the solubility of drug. Films were } \\
\text { prepared by solvent casting method using different polymers, } \\
\text { plasticizer, super disintegrant, saliva stimulant and sweetener. } \\
\text { Optimized film showed high } \% \text { drug release }(98.35 \%) \text { in } 12 \text { minutes }{ }^{32} \text {. }\end{array}$ \\
\hline $\begin{array}{l}\text { Haque et al., } \\
(2015)\end{array}$ & $\begin{array}{l}\text { Development of polymer- } \\
\text { bound fast-dissolving } \\
\text { metformin buccal film with } \\
\text { disintegrants }\end{array}$ & $\begin{array}{l}\text { Fast-dissolving films of metformin prepared by the solvent-casting } \\
\text { method using chitosan as bioadhesive polymer with starch, sodium } \\
\text { starch glycolate and microcrystalline cellulose as disintegrating agents } \\
\text { added in different ratios. The films were evaluated for various } \\
\text { parameters. The films were also subjected to in vitro dissolution study, } \\
\text { and the disintegration time was found to be less than } 30 \text { minutes for all } \\
\text { formulations. Formulation also showed } 92.2 \% \text { drug release within } 6 \\
\text { minutes } 33 \text {. }\end{array}$ \\
\hline $\begin{array}{l}\text { Thakur et } \\
\text { al., (2015) }\end{array}$ & $\begin{array}{l}\text { Formulation and evaluation } \\
\text { of fast dissolving film of } \\
\text { losartan potassium }\end{array}$ & $\begin{array}{l}\text { Fast dissolving films of losartan potassium for treatment of } \\
\text { hypertension prepared by solvent casting technique using The optimized } \\
\text { formulation showed satisfactory } \mathrm{pH} \text {, drug content } 98.54 \% \text {, in-vitro drug } \\
\text { release } 98.72 \% \text { in } 3 \text { min and disintegration time of } 12 \text { seconds }{ }^{34} \text {. }\end{array}$ \\
\hline $\begin{array}{l}\text { Rekha et al., } \\
(2015)\end{array}$ & $\begin{array}{l}\text { Formulation and evaluation } \\
\text { of fast dissolving buccal } \\
\text { film containing isradipine } \\
\text { solid dispersion. }\end{array}$ & $\begin{array}{l}\text { Fast dissolving buccal films containing solid dispersion of Isradipine, an } \\
\text { anti-hypertensive and used in the management of angina. Solid } \\
\text { dispersion of drug was prepared by fusion and evaporation technique } \\
\text { for better dissolution. The formulated films were evaluated for various } \\
\text { parameters. The results showed that as the concentration of Lycoat } \\
\text { RS720 increased the drug release rate decreased and as the } \\
\text { concentration of glycerin increased the drug release rate increased. } \\
\text { Formulation containing Lycoat RS720 and glycerin in } 2: 1 \text { showed } \\
98.89 \% \text { drug release from the film within } 7 \text { minutes }{ }^{35} \text {. }\end{array}$ \\
\hline
\end{tabular}




\begin{tabular}{|c|c|c|}
\hline $\begin{array}{l}\text { Pawar et al., } \\
(2015)\end{array}$ & $\begin{array}{l}\text { Formulation and evaluation } \\
\text { of mouth dissolving film of } \\
\text { risperidone. }\end{array}$ & $\begin{array}{l}\text { Mouth dissolving film of Risperidone for the treatment of } \\
\text { Schizophrenia prepared by solvent-casting method It was concluded } \\
\text { that Risperidone fast dissolving oral films can be formulated as a } \\
\text { potentially useful tool for an effective treatment of Schizophrenia with } \\
\text { improved bioavailability, rapid onset of action and with increased } \\
\text { patient compliance }{ }^{36} \text {. }\end{array}$ \\
\hline $\begin{array}{l}\text { Jelvehgari et } \\
\text { al., (2015) }\end{array}$ & $\begin{array}{l}\text { Fast dissolving oral thin } \\
\text { film drug delivery systems } \\
\text { consist of ergotamine } \\
\text { tartrate and caffeine } \\
\text { anhydrous. }\end{array}$ & $\begin{array}{l}\text { Fast dissolving oral thin films of Ergotamine tartrate and Caffeine } \\
\text { anhydrous prepared separately for the fast drug dissolution in the oral } \\
\text { cavity and thus bypassing first pass metabolism for providing quick } \\
\text { onset of action of the drug in migraine therapy. Oral films were } \\
\text { prepared by solvent casting }{ }^{37} \text {. }\end{array}$ \\
\hline $\begin{array}{l}\text { Goutam et } \\
\text { al., (2015) }\end{array}$ & $\begin{array}{l}\text { Formulation and evaluation } \\
\text { of oral fast dissolving films } \\
\text { of promethazine theoclate }\end{array}$ & $\begin{array}{l}\text { Promethazine Theoclate oral fast dissolving films prepared for the } \\
\text { treatment and management of nausea and vomiting. Films were } \\
\text { prepared by solvent casting method using various polymers such as } \\
\text { PVA, HPMC, HPMC-K15, HPMC-E50 and propylene glycol as } \\
\text { plasticizer, crospovidone as disintegrating agent, and citric acid as } \\
\text { saliva stimulating agent, tween- } 80 \text { as surfactant and aspartame as } \\
\text { artificial sweetener. Phosphate buffer PH } 6.8 \text { as dissolution media for } \\
\text { in-vitro drug release. The best formulation shown } 95.18 \% \text { drug release } \\
\text { at the end of } 135 \mathrm{sec}^{38} \text {. }\end{array}$ \\
\hline $\begin{array}{l}\text { Mundada et } \\
\text { al., (2015) }\end{array}$ & $\begin{array}{l}\text { Formulation, development } \\
\text { and optimization of fast } \\
\text { dissolving oral film of } \\
\text { montelukast sodium }\end{array}$ & $\begin{array}{l}\text { Fast dissolving oral film of montelukast sodium prepared using HPMC } \\
\text { E15 LV as film former and Musa paradisiaca fruit powder, as a novel } \\
\text { natural superdisintegrant by solvent casting method. A } 3^{2} \text { full factorial } \\
\text { design was employed for the optimization of developed formulation } \\
\text { considering concentration of superdisintegrant and concentration of film } \\
\text { former as independent variables with drug release and disintegration } \\
\text { time as dependent variables }{ }^{39} \text {. }\end{array}$ \\
\hline $\begin{array}{l}\text { Dwivedy et } \\
\text { al., (2014) }\end{array}$ & $\begin{array}{l}\text { Preparation and evaluation } \\
\text { of mouth dissolving film of } \\
\text { pantoprazole sodium. }\end{array}$ & $\begin{array}{l}\text { Mouth dissolving films of pantoprazole sodium, a highly potent proton } \\
\text { pump inhibitor by solvent casting technique using different film } \\
\text { forming polymers such as PVA, HPMC, HPC alone and in different } \\
\text { ratios along with Glycerin as plasticizer. Sodium saccharine was used as } \\
\text { artificial sweetener. Mouth dissolving films containing PVA and HPC } \\
\text { have good tensile strength and released } 99.55 \% \text { drug in one minute }{ }^{40} \text {. }\end{array}$ \\
\hline $\begin{array}{l}\text { Kumar et al., } \\
(2014)\end{array}$ & $\begin{array}{l}\text { Effects of maltodextrin and } \\
\text { glycerin on mechanical } \\
\text { properties of oral fast } \\
\text { dissolving film of } \\
\text { salbutamol sulphate }\end{array}$ & $\begin{array}{l}\text { Oral fast dissolving films of salbutamol sulphate were prepared. } \\
\text { Effects of maltodextrin and glycerin on mechanical properties of oral } \\
\text { fast dissolving film }{ }^{41} \text {. }\end{array}$ \\
\hline $\begin{array}{l}\text { Prabhu et } \\
\text { al., (2014) }\end{array}$ & $\begin{array}{l}\text { Formulation and Evaluation } \\
\text { of fast-dissolving films of } \\
\text { lisinopril. }\end{array}$ & $\begin{array}{l}\text { Oral fast-dissolving film of lisinopril for the management of } \\
\text { hypertension and cardiac diseases. Fast-dissolving films were prepared } \\
\text { by the solvent casting method using a combination of different } \\
\text { polymers and plasticizer. Evaluation of physical parameters such as } \\
\text { physical appearance, uniformity of weight, surface texture, uniformity } \\
\text { of strip thickness, surface pH, folding endurance and uniformity of } \\
\text { drug content were performed. Kinetic data analysis for the release study } \\
\text { and the stability study were also performed.. }\end{array}$ \\
\hline $\begin{array}{l}\text { Swamy et } \\
\text { al., (2014) }\end{array}$ & $\begin{array}{l}\text { Formulation and evaluation } \\
\text { of fast dissolving oral films } \\
\text { of palonosetron } \\
\text { hydrochloride using Hpmc- } \\
\text { E5 }\end{array}$ & $\begin{array}{l}\text { Oral films of Palonosetron by solvent casting technique were prepared } \\
\text { and evaluated. The prepared films of Palonosetron were evaluated for } \\
\text { parameters like thickness uniformity, weight uniformity, folding } \\
\text { endurance, percentage moisture loss, tensile strength, percentage } \\
\text { elongation, drug content uniformity, in-vitro disintegration time, in- } \\
\text { vitro dissolution studies }{ }^{43} \text {. }\end{array}$ \\
\hline $\begin{array}{l}\text { Pandey et } \\
\text { al., (2014) }\end{array}$ & $\begin{array}{l}\text { Fast dissolving sublingual } \\
\text { films of zolmitriptan: A } \\
\text { novel approach for migraine } \\
\text { attacks. }\end{array}$ & $\begin{array}{l}\text { Sublingual films of Zolmitriptan, an anti-migraine drug by solvent } \\
\text { casting method were formulated. The formulations prepared were } \\
\text { evaluated for their uniformity of weight, surface } \mathrm{pH} \text {, folding endurance, } \\
\text { disintegration time, mucoadhesion time, tensile strength, and percentage } \\
\text { elongation, content uniformity and } \% \text { drug release }{ }^{44} \text {. }\end{array}$ \\
\hline $\begin{array}{l}\text { Deepthi et } \\
\text { al., (2014) }\end{array}$ & $\begin{array}{l}\text { Formulation and evaluation } \\
\text { of fast dissolving oral films } \\
\text { of zolmitriptan }\end{array}$ & $\begin{array}{l}\text { Fast dissolving oral films of Zolmitriptan by solvent casting technique } \\
\text { using sodium alginate, guar gum, xanthan gum and aloe vera gel as film } \\
\text { forming agent's, Sodium starch glycolate as disintegrating agent, PEG- } \\
400 \text { as plasticizer and sodium saccharine as artificial sweetener. The }\end{array}$ \\
\hline
\end{tabular}




\begin{tabular}{|c|c|c|}
\hline & & $\begin{array}{l}\text { formulation containing sodium alginate shows disintegration time } 33 \\
\text { Sec. and In-vitro drug release of } 98.5 \% \text { within } 7 \text { minutes. } 45 .\end{array}$ \\
\hline $\begin{array}{l}\text { Kumar et al., } \\
(2013)\end{array}$ & $\begin{array}{l}\text { Formulation development } \\
\text { and in vivo evaluation of } \\
\text { zolmitriptan oral dissolving } \\
\text { films. }\end{array}$ & $\begin{array}{l}\text { Zolmitriptan oral dissolving films were prepared for migraine treatment } \\
\text { using different grades of HPMC E3, E6 and E15, Maltodextrin DE6 and } \\
\text { Xanthan gum as polymers. Citric acid as saliva stimulating agent, } \\
\text { propylene glycol as plasticizer, aspartame as artificial sweetener and } \\
\text { vanillin as flavouring agent by solvent casting technique. The optimized } \\
\text { formulation prepared using HPMC E15 showed minimum disintegration } \\
\text { time (10 sec), highest dissolution rate i.e. } 99 \% \text { of drug within } 8 \text { min and } \\
\text { satisfactory physicochemical properties } 46 \text {. }\end{array}$ \\
\hline $\begin{array}{l}\text { Patel et al., } \\
\text { (2013) }\end{array}$ & $\begin{array}{l}\text { Development and } \\
\text { optimization of fast } \\
\text { dissolving film of losartan } \\
\text { potassium }\end{array}$ & $\begin{array}{l}\text { Fast dissolving films of losartan potassium were prepared for the } \\
\text { treatment of hypertension. The fast dissolving films were prepared by } \\
\text { the solvent casting technique. Films were evaluated for drug content and } \\
\text { the drug loading capacity. The best formulation containing } 250 \mathrm{mg} \\
\text { HPMC-E15, } 50 \mathrm{mg} \text { HPMC E5, } 50 \mathrm{mg} \text { MCC and } 30 \% \mathrm{w} / \mathrm{w} \text { PEG-400 } \\
\text { has lowest disintegration time of } 30 \mathrm{sec} \text { and released } 99.64 \% \text { drug in } 10 \\
\text { minutes } 47 \text {. }\end{array}$ \\
\hline $\begin{array}{l}\text { Kathpalia et } \\
\text { al., (2013) }\end{array}$ & $\begin{array}{l}\text { Development and } \\
\text { Evaluation of Orally } \\
\text { Disintegrating Film of } \\
\text { Tramadol Hydrochloride. } \\
\text { Asian Journal of biomedical } \\
\text { and pharmaceutical sciences }\end{array}$ & $\begin{array}{l}\text { Orally disintegrating films of Tramadol Hydrochloride were prepared } \\
\text { which disintegrate within } 30 \text { seconds. Two polymers such as modified } \\
\text { pea starch (Lycoat RS } 720 \text { ) and pullulan were evaluated for film } \\
\text { forming capacity and were found to form thin, smooth films at } 25 \% \\
\text { w/w and } 2 \% \mathrm{w} / \mathrm{w} \text { concentration respectively }{ }^{48} \text {. }\end{array}$ \\
\hline $\begin{array}{l}\text { Bansal et } \\
\text { al., (2013) }\end{array}$ & $\begin{array}{l}\text { Investigation of polymers } \\
\text { alone and in combination } \\
\text { for the development of oral } \\
\text { thin film. }\end{array}$ & $\begin{array}{l}\text { Researchers work on different polymers such as Sodium carboxy } \\
\text { methyl cellulose ( Na CMC), Hydroxypropyl methyl cellulose(HPMC } \\
\text { E15, HPMC E5, HPMC K-15,HPMC K50), soluble starch, pectin, } \\
\text { gelatin glycerol and tween } 80 \text { alone and in combination for the } \\
\text { development of oral thin films. HPMC K15 films alone and in } \\
\text { combination were fo u } \mathrm{n} \text { to ha ve comparatively low folding } \\
\text { endurance and tend to produce viscous gel instead of disintegrating and } \\
\text { dissolving, combination of soluble starch with HPMC K15 even in low } \\
\text { concentration tend to produce films which were opaque and had poor } \\
\text { folding endurance } 49 \text {. }\end{array}$ \\
\hline $\begin{array}{l}\text { Nalluri et al., } \\
(2013)\end{array}$ & $\begin{array}{l}\text { Development and evaluation } \\
\text { of mouth dissolving films of } \\
\text { salbutamol sulfate }\end{array}$ & $\begin{array}{l}\text { Mouth dissolving films of Salbutamol Sulfate prepared. Hydroxy } \\
\text { propyl Methylcellulose of different viscosity grades as film former, } \\
\text { along with film modifier/solubilizing agents, polyvinyl pyrrolidone K30 } \\
\text { (PVP K30) and sodium lauryl sulphate (SLS) to formulate MDFs. } \\
\text { MDFs with } 13 \% \text { w/w of HPMC E5 gave better dissolution properties } \\
\text { compared to HPMC E15. The film prepared using HPMC E5 and } \\
\text { SLS showed the highest dissolution rate, suitable in vitro disintegration } \\
\text { time and satisfactory physico-mechanical properties }{ }^{50} \text {. }\end{array}$ \\
\hline $\begin{array}{l}\text { Panchal et } \\
\text { al., (2012) }\end{array}$ & $\begin{array}{l}\text { Formulation and evaluation } \\
\text { of mouth dissolving film of } \\
\text { ropinirole hydrochloride by } \\
\text { using pullulan polymers. }\end{array}$ & $\begin{array}{l}\text { Mouth dissolving films of Ropinirole Hydrochloride for treatment of } \\
\text { parkinson's disease and rest leg syndrome prepared by a solvent } \\
\text { casting method with the help of } 3^{2} \text { full factorial designs. Mouth } \\
\text { dissolving film of Ropinirole Hydrochloride containing pullulan as } \\
\text { polymer showed } 99.48 \pm 0.18 \% \text { drug release at } 60 \text { sec. }\end{array}$ \\
\hline $\begin{array}{l}\text { Choudhary } \\
\text { et al., (2011) }\end{array}$ & $\begin{array}{l}\text { Exploration of film forming } \\
\text { properties of film formers } \\
\text { used in the formulation of } \\
\text { rapid dissolving films }\end{array}$ & $\begin{array}{l}\text { Films were prepared by solvent casting method using different grades of } \\
\text { methocel, Polyox and natural gums as film formers. Films composed of } \\
\text { Pullulan in combination with Xanthan gum have good visual } \\
\text { appearance, excellent film forming capacity along with tensile strength } \\
5.56 \mathrm{~N} / \mathrm{mm} 2 \text {, disintegration time } 22 \text { seconds and dissolution time } 42 \\
\text { sec. }\end{array}$ \\
\hline $\begin{array}{l}\text { Mishra et } \\
\text { al., (2011) }\end{array}$ & $\begin{array}{l}\text { Formulation and } \\
\text { characterization of rapidly } \\
\text { dissolving films of cetirizine } \\
\text { hydrochloride using } \\
\text { pullulan as a film forming } \\
\text { agent }\end{array}$ & $\begin{array}{l}\text { Rapidly dissolving films of cetirizine hydrochloride using pullulan as } \\
\text { film forming polymer by solvent casting technique were prepared. It } \\
\text { was reported that } 5 \% \text { w } / \mathrm{v} \text { pullulan as film former,PEG- } 400 \text { as } \\
\text { plasticizer, aspartame as sweetener (is used to mask the bitter taste of } \\
\text { drug) along with passion fruit flavour and citric acid when casted on } \\
\text { Teflon base gives excellent transparent films with good physical } \\
\text { properties and disintegration and dissolution time within } 30 \text { seconds. }\end{array}$ \\
\hline $\begin{array}{l}\text { Saini et al., } \\
\text { (2011) }\end{array}$ & $\begin{array}{l}\text { Formulation, development } \\
\& \text { evaluation of oral fast } \\
\text { dissolving anti-allergic film } \\
\text { of levo cetrizine }\end{array}$ & $\begin{array}{l}\text { Fast dissolving film of levo cetrizine dihydrochloride by solvent casting } \\
\text { method using maltodextrin and HPMC E15 as the film forming } \\
\text { polymers were prepared. To decrease the disintegration time, } \\
\text { concentration of maltodextrin \& HPMC E } 15 \text { were optimized using } 2^{2}\end{array}$ \\
\hline
\end{tabular}




\begin{tabular}{|c|c|c|}
\hline & dihydrochloride. & $\begin{array}{l}\text { factorial designs. Disintegration time, drug release pattern, mouth } \\
\text { dissolving time and content uniformity were also evaluated. All the } \\
\text { formulations were showing approximately } 90 \% \text { drug release after } 5 \mathrm{~min} \\
\text { in simulated salivary fluid }(\mathrm{pH} 6.8){ }^{54} \text {. }\end{array}$ \\
\hline $\begin{array}{l}\text { Samta et al., } \\
(2011)\end{array}$ & $\begin{array}{l}\text { Optimization of formulation } \\
\text { of fast dissolving films } \\
\text { made of pullulan polymer. }\end{array}$ & $\begin{array}{l}\text { Fast dissolving films by solvent casting method using pullulan as film } \\
\text { forming agent due to its excellent film forming property. PEG, } \\
\text { propylene glycol, glycerine were used as plasticizers. Higher } \\
\text { concentration of polymer and plasticizer results in increase in-vitro } \\
\text { disintegration time and in-vitro dissolution time of films. PEG forms } \\
\text { translucent films whereas films containing glycerin takes longer time to } \\
\text { dry than films containing propylene glycol. Lower concentration of } \\
\text { pullulan and propylene glycol showed optimum performances }{ }_{55} \text {. }\end{array}$ \\
\hline $\begin{array}{l}\text { Choudhary } \\
\text { et al., (2011) }\end{array}$ & $\begin{array}{l}\text { Formulation and evaluation } \\
\text { of quick dissolving film of } \\
\text { levocetirizine } \\
\text { dihydrochloride }\end{array}$ & $\begin{array}{l}\text { Quick dissolving films of levocetirizine dihydrochloride by solvent } \\
\text { casting technique using carboxy methyl cellulose, hydroxy propyl } \\
\text { cellulose, and hydroxy propyl methyl cellulose as film forming } \\
\text { polymers were prepared. Neotame and citric acid were employed to } \\
\text { mask the bitter taste of drug. Optimized formulations were } \\
\text { disintegrated in } 23 \mathrm{sec} \text { and dissolved in } 55 \mathrm{sec} \text { time }\end{array}$ \\
\hline $\begin{array}{l}\text { Mishra et } \\
\text { al., (2011) }\end{array}$ & $\begin{array}{l}\text { Design and development of } \\
\text { rapidly dissolving films } \\
\text { using ion exchange resin for } \\
\text { taste masking. }\end{array}$ & $\begin{array}{l}\text { Designed and developed rapidly dissolving films of Cetirizine } \\
\text { hydrochloride (CTZ), a water soluble bitter drug using ion exchange } \\
\text { resin for taste masking. Films were formulated using Hydroxy propyl } \\
\text { methyl cellulose E3 LV ( and Hydroxy propyl cellulose-LF as film } \\
\text { forming polymers. PEG } 400 \text { as plasticizer and Ion exchange resin } \\
\text { Tulsion } 335 \text { was used for the purpose of taste masking by complex } \\
\text { formation with drug. The optimized batch was found to possess } 192 \mu \mathrm{m} \\
\text { thickness, in-vitro disintegration time } 65 \mathrm{~s} \text { and in-vivo disintegration } \\
\text { time } 30 \mathrm{~s} 57 \text {. }\end{array}$ \\
\hline $\begin{array}{l}\text { Raju et al., } \\
(2011)\end{array}$ & $\begin{array}{l}\text { Flash release oral films of } \\
\text { metoclopramide } \\
\text { hydrochloride for pediatric } \\
\text { use. }\end{array}$ & $\begin{array}{l}\text { Flash release oral films were prepared by solvent casting technique } \\
\text { using two water soluble polymers, hydroxyl propyl methyl cellulose-E6 } \\
\text { and sodium carboxy methyl cellulose. Glycerol was used as plasticizer, } \\
\text { sodium bicarbonate as disintegrating agent, Citric acid as an anti- } \\
\text { oxidant and saliva stimulating agent, Tween-80 as surfactant and } \\
\text { Saccharin sodium as sweetener }{ }^{58} \text {. }\end{array}$ \\
\hline $\begin{array}{l}\text { Patil et al., } \\
(2011)\end{array}$ & $\begin{array}{l}\text { Formulation and evaluation } \\
\text { of Montelukast sodium fast } \\
\text { dissolving films by using } \\
\text { Gelatin as a film base. }\end{array}$ & $\begin{array}{l}\text { Fast dissolving films of montelukast sodium by solvent casting method } \\
\text { using gelatin as film base with different concentrations of super } \\
\text { disintegrants like microcrystalline cellulose and crospovidone using } \\
\text { PEG } 400 \text { as plasticizer were prepared. The physicochemical parameters } \\
\text { of the fast dissolving films were evaluated. The formulation with } 4 \% \\
\text { crospovidone and } 10 \% \text { MCC shows a maximum cumulative percentage } \\
\text { drug release of } 98.35 \% \text { and } 95.57 \% \text { at the end of } 30 \text { min respectively }\end{array}$ \\
\hline $\begin{array}{l}\text { Choudhary } \\
\text { et al., } \\
(2011)\end{array}$ & $\begin{array}{l}\text { Formulation and } \\
\text { evaluation of fast } \\
\text { dissolving film of } \\
\text { levocetirizine } \\
\text { dihydrochloride using } \\
\text { different grades of } \\
\text { methocel. }\end{array}$ & $\begin{array}{l}\text { Fast dissolving films of levocetirizine dihydrochloride prepared } \\
\text { for the treatment of acute allergic rhinitis and chronic urticaria to } \\
\text { produce faster on set of action. Films were prepared by solvent } \\
\text { casting method using different grades of methocel K3, E3, E5, and } \\
\text { E15 as film former alone and in combination with PG, } \\
\text { PEG } 400 \text { and tween- } 80 \text { as plasticizer. Bitterness of levocetirizine } \\
\text { was masked by forming inclusion complex of levocetirizine } \\
\text { dihydrochloride with hydroxylpropylß-cyclodextrin }{ }^{60} \text {. }\end{array}$ \\
\hline $\begin{array}{l}\text { Mane et al., } \\
(2010)\end{array}$ & $\begin{array}{l}\text { Exploration of different } \\
\text { polymers for use in the } \\
\text { formulation of oral fast } \\
\text { dissolving strips. }\end{array}$ & $\begin{array}{l}\text { Researchers worked on different polymers for preparation of fast } \\
\text { dissolving strips such as HPMC E-15, HPMC K4M, HPMC E-5, PVA, } \\
\text { PVP, Gelatin, Eudragit RL100 and Pullulan along with different } \\
\text { excipients to get best one. }{ }^{61} \text {. }\end{array}$ \\
\hline $\begin{array}{l}\text { Murata et } \\
\text { al., (2010) }\end{array}$ & $\begin{array}{l}\text { Preparation of fast } \\
\text { dissolving films for oral } \\
\text { dosage from natural } \\
\text { polysaccharides. }\end{array}$ & $\begin{array}{l}\text { Researchers investigated release profiles of different water soluble and } \\
\text { slightly water soluble drugs from the fast dissolving oral films } \\
\text { prepared using natural polysaccharides such as Pullulan, sodium } \\
\text { alginate and sodium chondroitin sulfate as film formers }{ }^{62} \text {. }\end{array}$ \\
\hline $\begin{array}{l}\text { Chen et al., } \\
(2008)\end{array}$ & $\begin{array}{l}\text { Castable edible } \\
\text { pharmaceutical films }\end{array}$ & $\begin{array}{l}\text { Formulations scientists prepared fast dissolving/ extended release } \\
\text { edible films and evaluated for dissolution time, release profiles and film } \\
\text { strength. Benzocaine, caffeine, lidocaine and diphenylhydramine were } \\
\text { used as a model drugs. Hydroxy propyl methylcellulose, } \\
\text { methylcellulose and polyethylene oxide were used as a film forming } \\
\text { polymers. }\end{array}$ \\
\hline Cilurzo et & Fast dissolving films made & A film forming material maltodextrins was studied effect of \\
\hline
\end{tabular}




\begin{tabular}{|c|c|c|}
\hline al., (2008) & of maltodextrins & $\begin{array}{l}\text { plasticizer concentration for its application in the design of fast } \\
\text { dissolving films. Flexible films were obtained by using } 16-20 \% \mathrm{w} / \mathrm{w} \\
\text { glycerin. Casting, solvent evaporation and hot melt extrusion were used } \\
\text { as production technologies by adding sorbitan monooleate and } \\
\text { microcrystalline cellulose respectively }{ }^{64} \text {. }\end{array}$ \\
\hline $\begin{array}{l}\text { Okabea et } \\
\text { al., (2008) }\end{array}$ & $\begin{array}{l}\text { Development of an easily } \\
\text { swallowed film formulation. }\end{array}$ & $\begin{array}{l}\text { Easily swallowable film of glimepiride prepared using polyvinyl } \\
\text { alcohol and carboxyvinyl as film formers glycerin as plasticizer and } \\
\text { accesulfame potassium as sweetner. Film swells in mouth and turns into } \\
\text { a jelly by absorbing small amount of saliva from mouth for geriatric and } \\
\text { pediatric use } 65\end{array}$ \\
\hline $\begin{array}{l}\text { Dinge et al., } \\
(2008)\end{array}$ & $\begin{array}{l}\text { Formulation and evaluation } \\
\text { of fast dissolving films for } \\
\text { delivery of triclosan to the } \\
\text { oral cavity. }\end{array}$ & $\begin{array}{l}\text { Triclosan containing fast dissolving films for local delivery to oral } \\
\text { cavity were formulated. Various film forming agents, film modifiers and } \\
\text { polyhydric alcohols were evaluated for optimizing the composition } \\
\text { of fast dissolving films. The potential of poloxamer } 407 \text { and } \\
\text { hydroxypropyl- } \beta \text { - cyclodextrin to improve solubility of Triclosan was } \\
\text { investigated }{ }^{66} \text {. }\end{array}$ \\
\hline $\begin{array}{l}\text { Ali and } \\
\text { Quadir, } \\
(2007)\end{array}$ & $\begin{array}{l}\text { High molecular weight } \\
\text { povidone based films for } \\
\text { fast dissolving drug delivery } \\
\text { applications. }\end{array}$ & $\begin{array}{l}\text { High molecular weight povidone K-90 polymer as a film forming } \\
\text { excipient were evaluated for fast dissolving drug delivery applications. } \\
\text { It was evaluated in combination with povidone K- } 30 \text { and other kollidon } \\
\text { SR polymers. Fast dissolving films suitable for delivery of highly potent } \\
\text { drugs and vitamins could be formulated using the polymer povidone K } \\
90 \text { with auxiliary polymers. }{ }^{67} \text {. }\end{array}$ \\
\hline $\begin{array}{l}\text { Gohel et al., } \\
(2007)\end{array}$ & $\begin{array}{l}\text { Development of taste } \\
\text { masked film of valdecoxib } \\
\text { for oral use. }\end{array}$ & $\begin{array}{l}\text { Oral films of valdecoxib using Eudragit EPO and hydroxy propyl } \\
\text { methyl cellulose were developed. Glycerol, menthol and aspartame } \\
\text { were incorporated in the drug containing films as plasticizer, cooling } \\
\text { agent and sweetener respectively. The drug loading was } 10 \mathrm{mg} \text { per } 4 \\
\mathrm{~cm}^{2} \text { of the film. The films were evaluated for hydration study, folding } \\
\text { endurance and in vitro drug dissolution in the distilled water }{ }^{68} \text {. }\end{array}$ \\
\hline $\begin{array}{l}\text { Mashru et } \\
\text { al., (2005) }\end{array}$ & $\begin{array}{l}\text { Development and } \\
\text { evaluation of fast } \\
\text { dissolving film of } \\
\text { salbutamol sulphate. }\end{array}$ & $\begin{array}{l}\text { Fast dissolving films for sublingual route containing salbutamol } \\
\text { sulphate and polyvinyl alcohol as polymer ere developed and evaluated } \\
\text { for mechanical properties, in vitro release study and morphology study. } \\
\text { A } 3^{3} \text { factorial design was applied to study the effect of polyvinyl } \\
\text { alcohol, glycerin and mannitol on } \% \text { drug release and mechanical } \\
\text { properties of the films. It was observed that Mannitol produced positive } \\
\text { effect on drug release where as polyvinyl alcohol produced negative } \\
\text { effect on drug release } 69 \text {. }\end{array}$ \\
\hline
\end{tabular}

\section{CONCLUSION}

The key advantage for fast dissolving oral films is patient compliance and convenience. The main drawback is with drug loading. Drug loading is generally limited to roughly $40 \mathrm{mg}$. This problem can be solved by increasing the thickness of the film, but that in turn may increase the disintegration and dissolution time. Drug companies are still interested in this

\section{REFERENCES}

1. Liang CA, Chen HL. Fast dissolving intraoral drug delivery systems. Expert Opin. Ther. Patents. 2001; 11(6):981-986.

2. Ehtezazi T, Algellay M, Islam Y, Roberts M, Dempster NM, Sarker SD The Application of 3D Printing in the Formulation of Multilayered Fast Dissolving Oral Films. J Pharm. Sci 2018, 107(4):1076-1085

3. Habib W, Pritchard JF, Bozigian HP, Gooding AE, Griffin RH, Mitchell R, Bjurstrom T, Panella TL, Huang AT, Hansen LA. Fast-dissolve drug delivery system. Crit. Rev. Ther. Drug Carrier Syst. 2000; 17:61-72.

4. Siddiqui MD, Garg G, Sharma PA. Short review on: A novel approach in oral fast dissolving drug delivery system and their patents. Adv. Bio. Res. 2011; 5(6):291-303.

5. Brniak W, Jachowicz R, Pelka Przemyslaw. The practical approach to the evaluation of methods used to determine the technology as it provides fast, accurate dosing that is expected to increase patient compliance, particularly among pediatrics. There is no need for water or measuring and upon dissolution; the dose of drug is swallowed. Thus we can say that Fast-dissolving oral thin film offer fast, accurate dosing in a safe, efficacious format that is convenient and portable, without the need for water or measuring devices. disintegration time of orally disintegrating tablets. Saudi Pharm. J. 2015; 23:437-443.

6. Gisel EG. Oral motor skills following sensorimotor intervention the moderately eating impaired child with cerebral palsy. Dysphagia. 1994; 9:180-192.

7. Avery SW, Dellarosa DM. Approaches to treating dysphagia patients with brain injury. Am. J. Occup. Ther. 1994; 48(3):235-239.

8. Chauhan NS, Tomar A, Sharma K, Mittal A, Bajaj U. Formulation and evaluation of fast dissolving oral film of dicyclomine as potential route of buccal delivery. Int. J. Drug Dev. Res.2012; 4 (2):408-417.

9. Patel A, Shaikh S, Khan G J, Molvi KI, Patel H. Review Article: various aspects of oral fast disintegrating dosage form. Int. J. Pharmacy Pharm. Res. 2016; 6(4):689-701. 
10. Dixit RP, Puthli SP.Oral strip technology: Overview and future potential. J. Control. Release.2009; 139(2):94-107.

11. Arya A, Chandra A, Sharma V, Pathak K. Fast dissolving oral films: An innovative drug delivery system and dosage form. Int. J. Chem Tech. Res. 2010; 2(1):576-583.

12. Bhyan B, Jangra S, Kaur M, Singh H. Orally fast dissolving films: Innovations in formulation and technology. Int. J. Pharm. Sci. Rev. Res. 2011; 9(2):50-57.

13. Bala R, pravin pawar, sushil khanna, sandeep arora.Orally dissolving strips: A new approach to oral drug delivery system. Int. J. Pharm. Invest. 2013; 3(2):67-76.

14. Choudhary DR, Patel VA, Chhalotiya UK, Patel HV, Kundawala AJ. Development and characterization of pharmacokinetic parameters of fast-dissolving films containing levocetirizine. Sci. Pharm. 2012; 80:779-787.

15. Zhang H, Zhang J, Streisand JB. Oral mucosal drug delivery: clinical pharmacokinetics and therapeutic applications. Clin. Pharmacokinetic. 2002; 41(9):661-680.

16. Jangra PK, Sharma S, Bala R.Fast dissolving oral films: Novel way for oral drug delivery. Int. J. Uni. Pharm. Bio. Sci. 2014; 3(1):6-27.

17. Heer D, Aggarwal G, Kumar SLH. Recent trends of fast dissolving drug delivery system-An overview of formulation technology. Pharmacophore. 2013; 4(1):1-9.

18. Mahajan A, Chhabra N, Aggarwal G. Formulation and Characterization of Fast Dissolving Buccal Films: A Review. Der Pharm Lett. 2011; 3(1):152-165.

19. Rathi V, Senthil V, Kammili L, Hans R. A brief review on oral film technology. Int. J. Res. Ayur. Pharm. 2011; 2:11381147.

20. Kulkarni AS, Deokule HA. Exploration of different polymers for use in the formulation of oral fast dissolving strips. $\mathrm{J}$ Current Pharm. Res. 2010; 2(1):33-35.

21. Patel A, Prajapati DS, Raval JA. Fast dissolving films: as a newer venture in fast dissolving dosage forms. Int. J. Drug Dev. Res.2010; 2:232-246.

22. Kalyan S, Bansal M. Recent trends In the development of oral dissolving film. Int. J. Pharmtech Res. 2012; 4:725-733.

23. Patil D, Ahmed AH, Awais M, Akhtar S, Bairagi V. Design and development of fast dissolving film of telmisartan. Pharma Science Monitor. 2018; 9(1):171-187.

24. Song Q, Shen C, Shen, B, Lian W, Dai B, Yuan H. Development of a fast dissolving sublingual film containing meloxicam nanocrystals for enhanced dissolution and earlier absorption. Colloids and Surfaces B: Biointerfaces. 2018; 163(1): 9-18

25. Kadam V. S., Bharkad V. B., Shete G. A., Jameel A, Shendarkar G. R., and Jadhav S. V. Formulation and evaluation of fast dissolving oral film of metoclopramide hcl. World journal of pharmacy and pharmaceutical sciences. 2017; 6(8):2052-2066.

26. Bajpai S. K., Shah FF, Bajpai M, Jadaun M, Jyotish P. Dynamic release of Amoxicillin from Orally Dissolving Film (ODF) composed of Casein and Sodium alginate. J Drug Res Dev. 2017; 3(2): doi http://dx.doi.org/10.16966/24701009.134.

27. Patil JS, Deokar AB, Vilegave KV, Morani DO,Dhadde SB. Design, evaluation and characterization of rapidly dissolving oral strips of metoprolol succinate. J. Pharm. Analy. Insights.2016; 1(2):1-6.

28. Reddy S, Devi S, Naik V, Mounica NVN, Rao AA. Formulation and evaluation of fast dissolving buccal films conaining zolmitriptan. Int.J.Pharm. chem.Res. 2016; 1(1):129-140.

29. Newton AMJ, Rani SM, Sukhjinder K. Fabrication and evaluation of fast disintegrating oral hybrid films of propranolol hydrochloride by using pectin and synthetic polymers. J. Dev.Drugs.2016;5(2):157

30. Nair SS, Padamanabhan R, Sreena K.Development and Evaluation of fast dissolving oral thin film containing prochlorperazine maleate. Eur. J. Pharm. Medical Res. 2016; 3(1):379-384.

31. Pathan A, Gupta MK, Jain NK, Dubey A, Agarwal A. Formulation and evaluation of fast dissolving oral film of promethazine hydrochloride using different surfactant. J. Innov. Pharm. Bio.Sci.2016; 3(1):74-84.

32. Soni MM, Patel KR. Formulation and evaluation of fast dissolving film of lurasidone Hcl. Int. J. Pharm. Res. Bio.Sci.2016; 5(2):101-123.

33. Haque SE, Sheela A. Development of polymer-bound fastdissolving metformin buccal film with disintegrants. Int. J. Nanomedicine.2015; 10(1):199-205.

34. Thakur S, Raju L, Soni A, Agnihotri B. Formulation and evaluation of fast dissolving film of losartan potassium.World J. Pharmcol. Res. Tech.2015; 3(6):179-189.

35. Rekha MS, Sultana SKS, Mahathi K, Parveen P, Prathima B, Devi AS. Formulation and evaluation of fast dissolving buccal film containing isradipine solid dispersion. Amer. J. Pharmtech. Res.2015; 5(2):221-247.

36. Pawar SV, Junagade MS. Formulation and evaluation of mouth dissolving film of risperidone. Int. J. PharmTech. Res.2015; 8(6):218-230.

37. Jelvehgaril M, Montazam SH, Soltani S,Mohammadi R, Azar K,Montazam SA. Fast dissolving oral thin film drug delivery systems consist of ergotamine tartrate and caffeine anhydrous.Pharm.Sci.2015; 21:102-110.

38. Goutam K, Garg R, Sharma A, Singh A,Sharma P, Kaushal S. Formulation and evaluation of oral fast dissolving films of promethazine theoclate . Indo. Ameri.J.Pharm.Res.2015; 5(8):2536-2544.

39. Mundada AS, Jain RA. Formulation, development and optimization of fast dissolving oral film of montelukast sodium. Int. J. Drug Dev. Res.2015; 7(4):40-46.

40. Dwivedy BN, Dabral P, Kumar R. Preparation and evaluation of mouth dissolving film of pantoprazole sodium. World J. Pharm. Pharmceut. Sci.2014; 3(8):1564-1576.

41. Kumar R, Pandey GS, Sharma R, Singh Y, Teotia UVS. Effects of maltodextrin and glycerin on mechanical properties of oral fast dissolving film of salbutamol sulphate. Int. J. Adv. Pharm. Bio. Chem. 2014; 3(1):199-209.

42. Prabhu P, Dubey A, kamath K. formulation and Evaluation of fast-dissolving films of lisinopril. Egyp. Pharm. J.2015; 14:56-64.

43. Swamy NGN, Kumar SS. Formulation and evaluation of fast dissolving oral films of palonosetron hydrochloride using Hpmc-E5.Int.J. Pharm. Chem. Sci.2014; 3(1):145-150.

44. Pandey P, Chauhan S.Fast dissolving sublingual films of zolmitriptan : A novel approach for migraine attacks.Ind.J.Pharm. Edu. Res.2014; 48(1):67-72.

45. Deepthi A, Reddy V, Navaneetha K. Formulation and evaluation of fast dissolving oral films of zolmitriptan. Ameri. J. Adv. Drug Deliv.2014; 2(2):153-163.

46. Kumar SK, Nagabhushanam MV, Sambasiva Rao KRS, Bhikshapathi DVRN. Formulation development and in vivo evaluation of zolmitriptan oral dissolving films.Int.J.Pharm.Bio.Sci.2013; 4(3):638-654

47. Patel HJ, Patel PB,Kamdar KM, Patel KB,Shah AA, Patel ZP. Development and optimization of fast dissolving film of losartan potassium. Amer. J. Pharm. Health Res.2013; 1(2):35-44.

48. Kathpalia H, Sule B, Gupte A. Development and Evaluation of Orally Disintegrating Film of Tramadol Hydrochloride. Asian Journal of biomedical and pharmaceutical sciences. 2013; 3(24):27-32.

49. Bansal G, Garg V, Siddiqui MD. Investigation of polymers alone and in combination for the development of oral thin film. Int.J.Inv.Pharm.Sci. 2013; 1(3):31-235.

50. Nalluri Buchi N., Sravani B., Maheswari K.M., Srianusha Sai V., Bramhini. R. Sri. Development and evaluation of mouth dissolving films of salbutamol sulfate. Journal of Chemical and Pharmaceutical Research. 2013; 5(3):53-60.

51. Panchal Mital S., Patel Hiren, Bagada Aarti, Dr. Vadalia K.R. Formulation and Evaluation of Mouth Dissolving Film of Ropinirole Hydrochloride by Using Pullulan Polymers. International Journal of Pharmaceutical Research \& Allied Sciences. (2012); 1(3):60-72.

52. Choudhary DR, Patel V, Patel H. Exploration of film forming properties of film formers used in the formulation of rapid 
dissolving films. International Journal of Chem Tech Research. 2011; 3(2):531-533.

53. Mishra R, Amin A. Formulation and Characterization of Rapidly Dissolving Films of Cetirizine hydrochloride using Pullulan as a Film Forming Agent. Indian Journal of Pharmaceutical Education and Research. 2011; 45(1):71-77.

54. Saini S, Nanda A., Dhari J. Formulation, Development \& Evaluation of Oral Fast Dissolving Anti-Allergic Film of Levo cetrizine Dihydrochloride. J. Pharm. Sci. \& Res. 2011; 3(7):1322-1325.

55. Samta, Saini S, Rana A.C., Gupta S. Optimization of formulation of fast dissolving films made of pullulan polymer. International Journal of Pharmaceutical Sciences Review and Research. 2011; 9(1):127-132.

56. Choudhary DR, Patel VA, Patel HV, Kundawalal AJ. Formulation and evaluation of quick dissolving film of levocetirizine dihydrochloride. International Journal of Pharmacy \& Technology. 2011; 3(1):1740-1749.

57. Mishra R, Amin A. Design and development of rapidly dissolving films using ion exchange resin for taste masking. International Journal of Drug Formulation \& Research. 2011; 2(2):314-343.

58. Raju S., Reddy P. Sandeep, V. Anirudh Kumar, A. Deepthi, K. Sreeramulu Reddy, P.V. Madhava Reddy. Flash release oral films of metoclopramide hydrochloride for pediatric use:Formulation and in-vitro evaluation. J. Chem. Pharm. Res. 2011; 3(4):636-646.

59. Patil AK, GhorwadeVK, Patil S, Ikkurthi K, Inuganti KS, Porandla V. Formulation and evaluation of Montelukast sodium fast dissolving films by using Gelatin as a film base. Research Journal of Pharmaceutical, Biological and Chemical Sciences. 2011; 2(3):880-887.
60. Choudhary DR, Patel Vishnu A, Chhalotiya Usmangani K., Patel Harsha V, Kundawala Aliasgar J. Formulation and Evaluation of Fast Dissolving Film of Levocetirizine Dihydrochloride Using Different Grades of Methocel. Journal of Pharmacy Research. 2011; 4(9):2919-2924.

61. Mane M.S., Kulkarni A. S., Deokule H.A., Ghadge D. M. Exploration of different polymers for use in the formulation of oral fast dissolving strips. Journal of current pharmaceutical research. 2010; 2(1):33-35.

62. Murata Y, Isobe T, Kofuji K, Norihisa N. Preparation of Fast Dissolving Films for Oral Dosage from Natural Polysaccharides. Materials. 2010; 3:4291-4299.

63. Chen MJ, Tirol G, Bass C, Corniello CM, Watson G, Sanchez I, " Castable edible pharmaceutical films", Drug Del Tec. 2008; 8(6):35-41.

64. Cilurzo F, Cupone I, Minghetti P, Selmin F, Montanari L, “ Fast dissolving films made of maltodextrins", Eur J Pharm Biopharm. 2008; 70(3):895-900.

65. Hideaki O, Eiji S, Yusaku S, Kaisuke Y, Yasunari T. Development of an easily swallowed film formulation. Journal of Pharmaceutics. 2008; 355:62-66.

66. Dinge A, Nagarsenker M. Formulation and Evaluation of Fast Dissolving Films for Delivery of Triclosan to the Oral Cavity. AAPS Pharm Sci Tech. 2008; 9(2): 349-356.

67. Ali S, Quadir A. High molecular weight povidone based films for fast dissolving drug delivery applications. Drug Del Tech. 2007; 7(6):36-43.

68. Gohel MC, Sharma Renuka, Parikh RK., Soniwala MM. Development of taste masked film of valdecoxib for oral use. Indian J Pharm Sci. 2007; 69(2):320-323.

69. Mashru RC, Sutariya VB, Sankalia MG, Parikh PP. Development and evaluation of fast dissolving film of salbutamol sulphate. Drug Dev Ind Pharm. 2005; 1: 25-34. 